\title{
Rare earth element and yttrium analyses of sulfides from the Dachang Sn-polymetallic ore field, Guangxi Province, China: Implication for ore genesis
}

\author{
KUI-DONG ZHAO and SHAO-YONG JIANG* \\ State Key Laboratory for Mineral Deposits Research, Department of Earth Sciences, Nanjing University, \\ Nanjing, 210093, China
}

(Received March 25, 2006; Accepted January 29, 2007)

\begin{abstract}
The Dachang Sn-polymetallic ore field (Guangxi, China) is one of the largest tin deposits in the world with a tin reserve of above $10^{6}$ tons. Several types of orebody occur in this giant ore field, including mainly the Lamo $\mathrm{Cu}-\mathrm{Zn}$ skarns at the contact of Devonian limestone and the Cretaceous Longxianggai granite, the Changpo-Tongkeng stratiform $\mathrm{Sn}-\mathrm{Pb}-$ $\mathrm{Zn}$ ores in Devonian siliceous rocks, and the Gaofeng massive sulfide ore in Devonian reef limestone. Rare-earth element (REE) and yttrium concentrations in sulfides from different orebody types have been determined by ICP-MS. Sulfides from the Lamo skarn-type $\mathrm{Cu}-\mathrm{Zn}$ mines display significant LREE-enriched pattern with large negative Eu anomalies. This is in agreement with the mineralizing fluid being of magmatic hydrothermal origin. However, sulfides from massive and stratiform orebodies show significantly different REE distributions. The Gaofeng massive sulfides have very low total REE concentrations and REE patterns range from (1) being strongly enriched in light REE with positive Eu anomalies, to (2) relatively flat patterns with strongly negative Ce and positive Eu anomalies. Pattern 1 resembles REE distributions in modern submarine hydrothermal fluids. Pattern 2 exhibits both seawater and hydrothermal vent-fluid characteristics. Sulfides from stratiform orebodies at Changpo-Tongkeng are LREE-enriched with small or no negative Eu anomalies. REE patterns of sulfides from different stratiform orebodies are slightly different, but they are similar to those of each host rock. It indicates that the sulfides and host rocks are synsedimentary and that their REE patterns are controlled by the local physical-chemical environments. Y/Ho atomic weight ratios of granite, skarn and sulfides at Lamo vary from 26.3 to 33.7, close to the chondritic Y/Ho ratio. But sulfides from massive and stratiform ores have more variable $\mathrm{Y} / \mathrm{Ho}$ ratios (28.4-134) that are similar to those of many modern hydrothermal fluids. Hence, the ore-forming fluids responsible for mineralization of the stratiform and massive ores at Dachang were likely to be of exhalative hydrothermal origin. It is suggested that the Dachang deposits are formed through a two-stage hydrothermal process, i.e., the Devonian submarine hydrothermal ore-forming stage and the Yanshanian magmatic-hydrothermal ore-forming stage.
\end{abstract}

Keywords: REE and Y, sulfide, submarine hydrothermal, magmatic hydrothermal, ore genesis, Dachang ore field

\section{INTRODUCTION}

The Dachang Sn-polymetallic ore field in South China (Nandan Country, Guangxi Province) is a well-known world-class massive sulfide deposit with a tin reserve of about $10^{6}$ tons. In general, most primary Sn mineralization in the world has a magmatic hydrothermal origin associated with granitic intrusive rocks (e.g., Heinrich, 1990). Economic enrichments of Sn occur rarely in massive sulfide deposits except for the Kidd Creek (Ontario), the Geco (Ontario), the Neves-Corvo (Portugal) and the Sullivan (British Columbia) deposits (Campbell et al., 1980; Petersen, 1986). Influenced by the classical opinion, some researchers suggested that all of the orebodies

\footnotetext{
*Corresponding author (e-mail: shyjiang@nju.edu.cn)

Copyright (c) 2007 by The Geochemical Society of Japan.
}

in Dachang are skarns or replacements, associated with the Yanshanian magmatic hydrothermal events (e.g., Chen et al., 1993; Fu et al., 1991, 1993). But recently increasing evidence has not supported this genetic model (Han et al., 1993, 1997; Jiang et al., 1999; Zhao et al., 2002, 2006), and an alternative model of a submarine hydrothermal exhalative (sedex-type) origin for the stratiform and massive ores at Dachang has been proposed (Han et $a l ., 1997)$. In order to further understanding of the ore genesis in this deposit, more systematic and detailed geochemistry and isotope data are needed.

The behavior of rare-earth elements (REE) in hydrothermal systems has been the subject of many geochemical studies. REE analysis has been carried out on fluids emanating from active sea-floor systems, hydrothermal precipitates and hydrothermally altered rocks recovered from active and ancient hydrothermal deposits (Bach et al., 2003; and reference therein). Recently, Marques et al. 


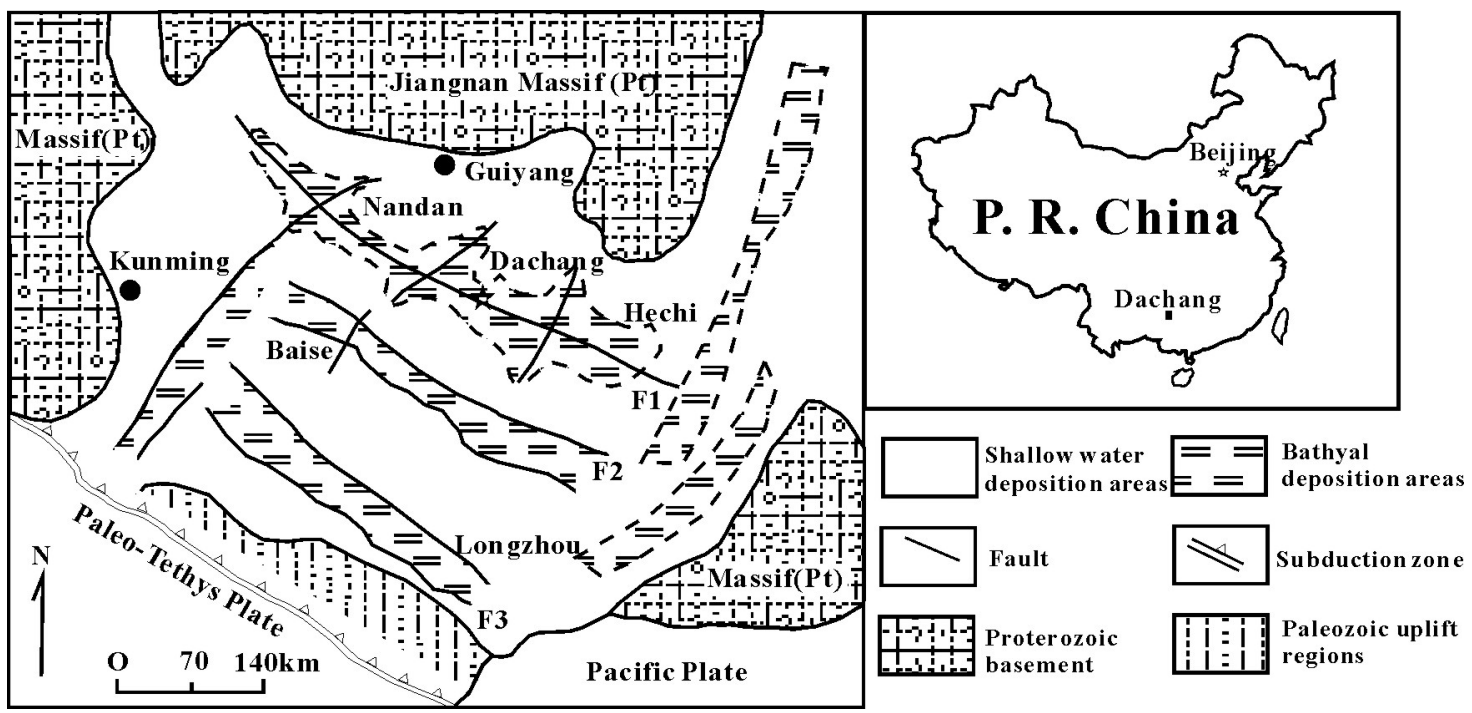

Fig. 1. Palinspastic and paleotectonic map from Middle to Late Devonian in South China (modified after Chen, 1988).

(2006) reported a data set of massive sulfide deposits and host rocks in the Rainbow hydrothermal field in Mid-Atlantic Ridge, and Allen and Seyfried (2005) reported experimental laboratory work focusing on REE mobility. Terakado and Walker (2005) studied the REE composition of Kuroko deposits that are considered as having formed during Miocene submarine hydrothermal activity. At Dachang, previous geochemical studies have provided a lot of trace element and REE data for igneous rocks (Chen et al., 1993) and host rocks (e.g., siliceous rocks, Han et al., 1997; tourmaline, Jiang et al., 1999; black shale, Fan et al., 2004), but systematic and reliable data on sulfide ores are lacking. Therefore, this study directly focuses on the rare earth element analyses of sulfides in an attempt to provide a more thorough geochemical characterization of the different types of sulfide mineralization at the Dachang ore field.

\section{Geological Setting}

The Dachang Sn-polymetallic ore field is located in the middle of the Danchi (Nandan-Hechi) Devonian rift basin, which flanks the southwest border of Jiangnan Massif (Fig. 1). The rift trough is a downfaulted basin controlled by synsedimentary structures. It trends northwest, parallel to the Jinsha River-Honghe River oceanic basin. The sedimentary rocks in the district range in age from Lower Devonian to Tertiary with a total thickness of 4,000 m, but the Middle-Upper Devonian strata are the most important host rocks for mineralization. The Middle Devonian rocks represent a shallow-water carbonate reef, developed in the marginal platform near the Nandan trough. The Upper Devonian rocks are typical intraplatform trough sediments, composed mainly of thick- to thin-layered massive, laminated and banded chert (siliceous rocks), limestone, and siliceous black shales (Fan et al., 2004). The Longxianggai granite is the main intrusive body in the Dachang region. It outcrops in the middle of the Dachang ore field and has an outcropped area of only $0.5 \mathrm{~km}^{2}$ (Fig. 2). The granite was intruded during the Yanshanian magmatic-hydrothermal event with a $\mathrm{Rb}-\mathrm{Sr}$ age of $99 \mathrm{Ma}(\mathrm{Xu}, 1987)$. The granite contains 36 percent quartz, 38 percent $\mathrm{K}$ feldspar, 22 percent plagioclase, 3 percent muscovite and 1 percent biotite. It is S-type, ilmenite-bearing, and peraluminous, with a high average $\delta^{18} \mathrm{O}$ values $(>10 \%)(\mathrm{Xu}, 1987)$.

The Dachang Sn-polymetallic ore field is the second largest $\mathrm{Sn}$ producer in China and has a resource of about $100 \mathrm{Mt}$ of ore at $1 \% \mathrm{Sn}$ (Table 1). It is also an important source of $\mathrm{Zn}, \mathrm{Pb}, \mathrm{Cu}, \mathrm{Ag}, \mathrm{Sb}$, In, and $\mathrm{Cd}$. There are four major types of Sn-polymetallic ore bodies: (a) stratabound, bedded and massive ores; (b) vein-type ores; (c) stockwork-type ores; and (d) skarn ores. The Dachang ore field can be subdivided into several deposits, including the Lamo, Changpo-Tongkeng, and Gaofeng deposits (Fig. 2). Some small mineralizing veins also occur in the eastern part of the Dachang ore field such as the Dafulou, Huile, and Kangma deposits (Fig. 2).

The Lamo deposit consists of mainly skarn-type mineralization, which occurs at the contact between Upper Devonian limestones and the Longxianggai granite that intruded them (Fig. 3). The orebodies at Lamo occur as chimneys, mantos, and pods in the skarns. Ore contains about $2 \% \mathrm{Cu}$ and $5 \% \mathrm{Zn}$, whereas the tin content in the skarn ore is usually less than $0.1 \%$.

The Changpo-Tongkeng deposit is about $5 \mathrm{~km}$ south- 


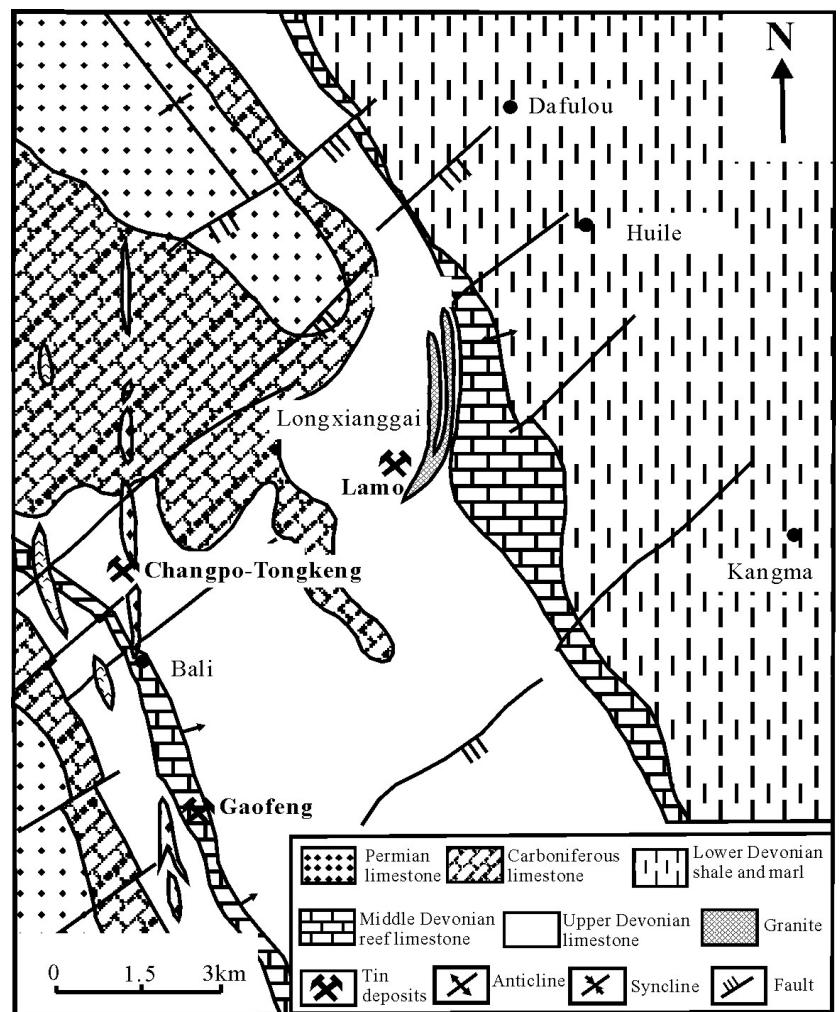

Fig. 2. Simplified geological map of the Dachang Snpolymetallic ore field, Guangxi Province, China.
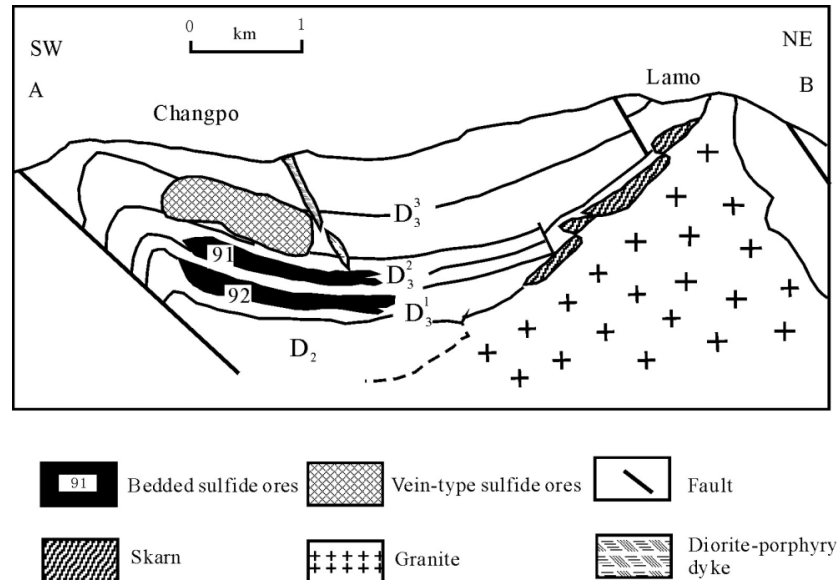

Fig. 3. Cross-section through Changpo, Lamo and the Longxianggai granite body at Dachang.

west of the outcrop of the Longxianggai granite (Fig. 2). In this deposit, stratiform, bedded, laminated orebodies are the most primary types, which are hosted within Upper Devonian banded siliceous rocks and carbonates and are conformable with the host rocks in general. Orebodies 91 and 92 are two of the largest stratiform orebodies (Fig.

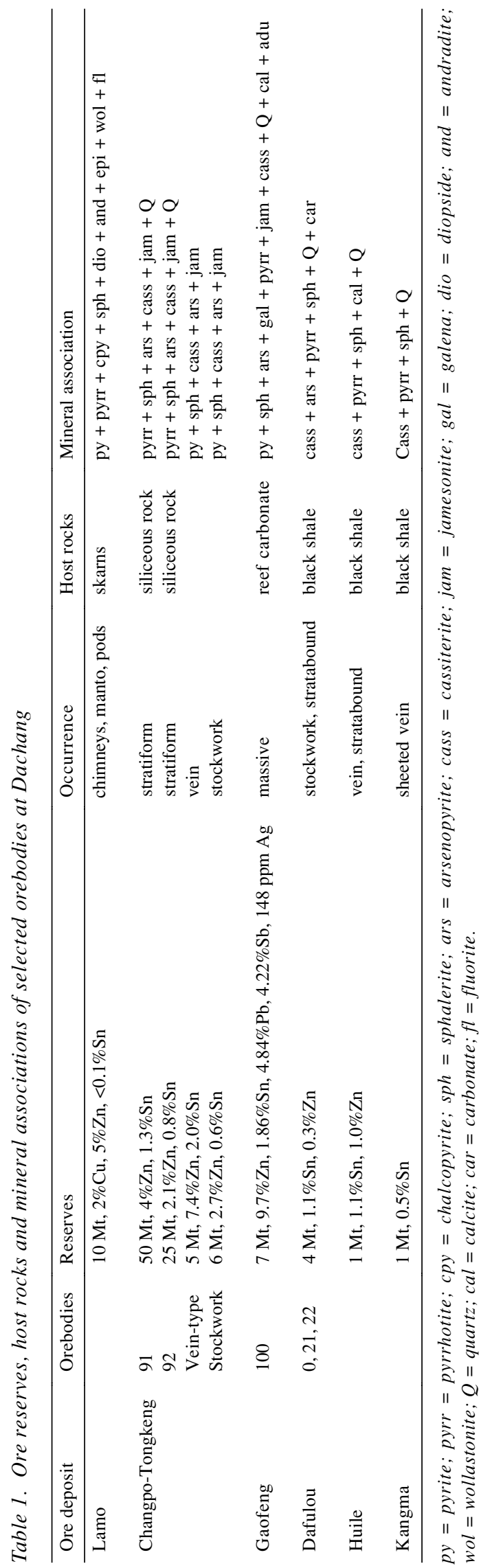

REE and $\mathrm{Y}$ in sulfides from the Dachang deposit, China 


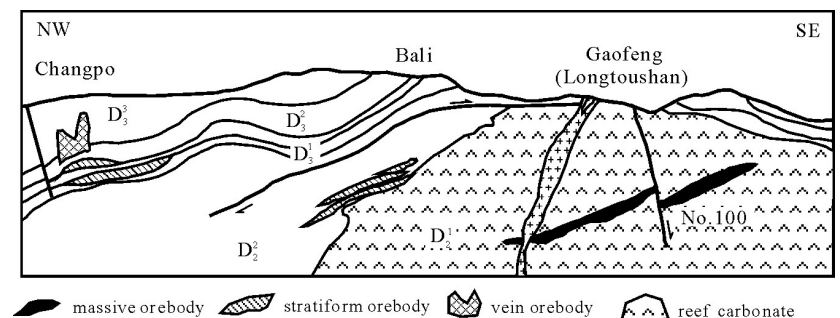

Fig. 4. Cross-section through Changpo and Gaofeng deposits at Dachang.

3), which contain 50 and $25 \mathrm{Mt}$ of ore, respectively, at about $1 \%$ tin and $2-4 \% \mathrm{Zn}$. The mineral assemblage includes cassiterite, pyrite, sphalerite, pyrrhotite, jamesonite and arsenopyrite. Vein and stockwork-type orebodies occur in the upper part of the deposit and contain 5 and 6 Mt ore, respectively (Fig. 3). Vein-type orebodies have relatively high average $\mathrm{Zn}(7.4 \%)$ and $\mathrm{Sn}(2.0 \%)$ contents, compared to the stockwork-type orebodies (average $\mathrm{Zn}=2.7 \%$; average $\mathrm{Sn}=0.6 \%)(\mathrm{Fu}$ et al., 1991).

The Gaofeng deposit is located $3 \mathrm{~km}$ south of the Changpo-Tongkeng deposit and is mainly composed of No. 100 orebody. No. 100 orebody occurs as a domical lens hosted by Middle Devonian reef limestones and contains massive sulfides and cassiterite (Fig. 4). The massive orebody contains about $7 \mathrm{Mt}$ of ore and has the highest grade ores in the Dachang tin deposit, with average $1.86 \% \mathrm{Sn}, 9.7 \%$ of $\mathrm{Zn}, 4.84 \%$ of $\mathrm{Pb}, 4.22 \% \mathrm{Sb}$, and 148 $\mathrm{g} / \mathrm{t} \mathrm{Ag}$. The orebody has no altered contact with host rocks except for a recrystallization calcite boundary with a width of about $1 \mathrm{~cm}$ locally at some of the contact between orebody and reef limestones (Han et al., 1997).

\section{SAMPLing AND ANALYTICAL MethodS}

In this study, samples were obtained in the Dachang ore field from the Changpo-Tongkeng stratiform orebodies, the Gaofeng No. 100 massive orebodies and the Lamo orebodies. Since minor clastic or accessory minerals may yield relatively high REE contents (Slack et al., 2000), high purity (>99\%) sulfide samples (pyrite and sphalerite) were separated from sulfide ores by carefully hand picking under a binocular microscope. These sulfides were cleaned ultrasonically in Milli-Q Water before dissolution. About $50 \mathrm{mg}$ sample was then placed in a capped Teflon beaker with mixed acids of $\mathrm{HCl}+\mathrm{HNO}_{3}$ at $\sim 120^{\circ} \mathrm{C}$ for $1 \sim 2$ days until the sulfide was completely digested. $\mathrm{HCl}$ was then removed by two cycles of heating to incipient dryness and addition of $1 \mathrm{ml} \mathrm{HNO}_{3}$. The dried sample was diluted in $50 \mathrm{ml} 3 \% \mathrm{HNO}_{3}$ spiked with $10 \mathrm{ppb}$ Rhodium to serve as an internal standard. Two granite and three skarn samples collected from the Lamo deposit were digested with mixed acids of $\mathrm{HF}+\mathrm{HNO}_{3}+$
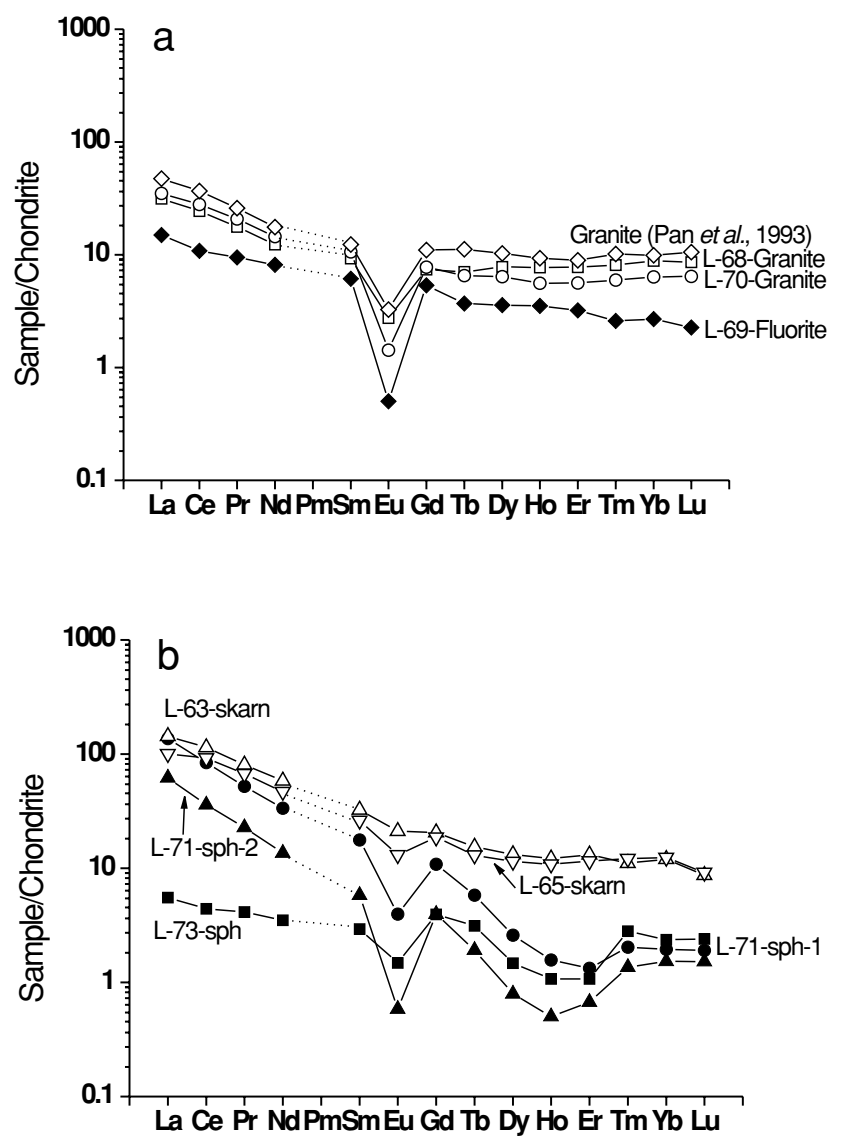

Fig. 5. Chondrite-normalized REE patterns of granite and fluorite (a), and skarns and sulfides (b) at Lamo.

$\mathrm{HClO}_{4}$ and diluted in a similar manner. REE and $\mathrm{Y}$ concentrations of the sample solutions were then analyzed using a Finnigan MAT Element II ICP-MS (inductively coupled plasma mass spectrometry) at State Key Laboratory for Mineral Deposits Research in Nanjing University. The detection limit values for REE are: La, $1.5 \mathrm{ppt}$; $\mathrm{Ce}, 3.2 \mathrm{ppt}$; Pr, $0.2 \mathrm{ppt}$; Nd, 1.5 ppt; Sm, 0.2 ppt; Eu, 0.8 ppt; Gd, 0.6 ppt; Tb, 0.1 ppt; Dy, 0.6 ppt; Ho, 0.1 ppt; Er, $0.1 \mathrm{ppt} ; \mathrm{Tm}, 0.1 \mathrm{ppt}$; Yb, $0.2 \mathrm{ppt}$; Lu, $0.2 \mathrm{ppt}$; and Y, 0.2 ppt, respectively (Gao et al., 2003). Since the sulfide samples contain very low $\mathrm{Ba}$, the $\mathrm{BaO}$ interferences with $\mathrm{Eu}$ during analysis were insignificant. Due to the lack of suitable sulfide standard, we used a basalt standard as an internal check during our sample run. Accordingly, the analytical precision for the samples is estimated to be better than $10 \%$ for most elements.

\section{RESULTS}

REE and $Y$ data at Lamo

Compositions of REE and $\mathrm{Y}$ of granites, skarns, fluorite and sulfides sampled at the Lamo deposit are listed 
Table 2. Rare earth element and Y compositions of granite, fluorite, skarns and sulfides from the Lamo skarn deposit in the Dachang ore field (in ppm)

\begin{tabular}{|c|c|c|c|c|c|c|c|c|c|c|}
\hline & $\begin{array}{l}\text { L-68 } \\
\text { granite }\end{array}$ & $\begin{array}{l}\text { L-70 } \\
\text { granite }\end{array}$ & $\begin{array}{c}\text { Pan, } 1993 \\
\text { granite }\end{array}$ & $\begin{array}{l}\text { L-71-Sph-1 } \\
\text { Sph }\end{array}$ & $\begin{array}{c}\text { L-73-2 } \\
\text { Sph }\end{array}$ & $\begin{array}{c}\text { L-71-Sph-2 } \\
\text { Sph }\end{array}$ & $\begin{array}{c}\text { L-69-Fl } \\
\text { Fl }\end{array}$ & $\begin{array}{l}\text { L-63 } \\
\text { skarn }\end{array}$ & $\begin{array}{l}\text { L-64 } \\
\text { skarn }\end{array}$ & $\begin{array}{l}\text { L-65 } \\
\text { skarn }\end{array}$ \\
\hline $\mathrm{La}$ & 9.73 & 10.8 & 14.6 & 42.5 & 19.2 & 69.8 & 4.64 & 44.5 & 14.7 & 31.2 \\
\hline $\mathrm{Ce}$ & 19.7 & 22.6 & 29.6 & 68.0 & 29.0 & 117 & 8.76 & 92.2 & 31.5 & 74.5 \\
\hline $\operatorname{Pr}$ & 2.15 & 2.54 & 3.16 & 6.36 & 2.78 & 10.8 & 1.16 & 9.84 & 3.74 & 8.20 \\
\hline $\mathrm{Nd}$ & 7.41 & 8.69 & 10.6 & 20.1 & 8.14 & 33.0 & 4.90 & 34.9 & 13.6 & 28.2 \\
\hline Sm & 1.81 & 2.07 & 2.41 & 3.45 & 1.13 & 4.78 & 1.20 & 6.32 & 2.43 & 5.12 \\
\hline Eu & 0.20 & 0.11 & 0.24 & 0.29 & 0.04 & 0.38 & 0.04 & 1.55 & 0.60 & 0.96 \\
\hline $\mathrm{Gd}$ & 1.91 & 2.02 & 2.86 & 2.80 & 1.02 & 2.45 & 1.38 & 5.33 & 2.24 & 4.84 \\
\hline $\mathrm{Tb}$ & 0.34 & 0.31 & 0.53 & 0.28 & 0.09 & 0.19 & 0.18 & 0.73 & 0.30 & 0.62 \\
\hline Dy & 2.52 & 2.07 & 3.31 & 0.83 & 0.26 & 0.80 & 1.15 & 4.27 & 1.86 & 3.69 \\
\hline Ho & 0.56 & 0.40 & 0.67 & 0.11 & 0.04 & 0.11 & 0.25 & 0.87 & 0.38 & 0.78 \\
\hline Er & 1.63 & 1.18 & 1.88 & 0.28 & 0.14 & 0.27 & 0.67 & 2.77 & 1.06 & 2.44 \\
\hline $\mathrm{Tm}$ & 0.26 & 0.19 & 0.33 & 0.07 & 0.04 & 0.03 & 0.08 & 0.36 & 0.16 & 0.39 \\
\hline $\mathrm{Yb}$ & 1.85 & 1.33 & 2.07 & 0.41 & 0.32 & 0.27 & 0.56 & 2.51 & 1.07 & 2.59 \\
\hline $\mathrm{Lu}$ & 0.28 & 0.21 & 0.34 & 0.06 & 0.05 & 0.04 & 0.07 & 0.28 & 0.19 & 0.29 \\
\hline $\mathrm{Y}$ & 15.1 & 11.1 & 18.5 & 2.96 & 1.21 & 2.97 & 20.2 & 25.2 & 10.05 & 21.6 \\
\hline REE & 50.4 & 54.5 & 72.6 & 145.6 & 62.3 & 239.9 & 25.1 & 206.5 & 73.8 & 163.8 \\
\hline LREE/HREE & 4.4 & 6.1 & 5.1 & 29.1 & 30.8 & 56.9 & 4.8 & 11.1 & 9.2 & 9.5 \\
\hline $\mathrm{Eu} / \mathrm{Eu}^{*}$ & 0.3 & 0.2 & 0.3 & 0.3 & 0.1 & 0.3 & 0.09 & 0.8 & 0.8 & 0.6 \\
\hline $\mathrm{Ce} / \mathrm{Ce}^{*}$ & 1.0 & 1.0 & 1.0 & 0.9 & 0.9 & 0.9 & 0.9 & 1.0 & 1.0 & 1.1 \\
\hline Y/Ho & 27.2 & 27.6 & 27.5 & 26.2 & 33.7 & 26.5 & 79.7 & 28.9 & 26.3 & 27.7 \\
\hline
\end{tabular}

in Table 2 and shown in Fig. 5 after normalization using the average $\mathrm{C} 1$ chondrite abundances of Boynton (1984). The Longxianggai granites display slightly light-REE enrichments (LREE/HREE = 4.4 6.1) and negative Eu anomalies $\left(\mathrm{Eu} / \mathrm{Eu}^{*}=0.2 \sim 0.3\right)$. A fluorite sample (L-69$\mathrm{Fl})$ collected from a fluorite-quartz vein adjacent to the granite display a similar REE pattern to the granite samples (Fig. 5a). The sulfide samples (L-71-Sph and L-73Sph) show higher REE abundances (62.3 240 ppm), more LREE-enriched (LREE/HREE $=29.1 \sim 56.9)$, but similar negative Eu anomalies $\left(\mathrm{Eu} / \mathrm{Eu}^{*}=0.1 \sim 0.3\right)$ (Fig. 5b). The skarn samples also show slightly LREE enrichments (LREE/HREE $=9.2 \sim 11.1)$ and small negative Eu anomalies $\left(\mathrm{Eu} / \mathrm{Eu}^{*}=0.6 \sim 0.8\right)$ (Fig. 5b).

In order to examine REE fractionation observed in the pairs among granite, skarn, fluorite, and sulfides directly, we made a plot of logarithmic REE concentration ratios against the atomic number of REE (Fig. 6). The reported fluorite (L-69) and skarn (L-63) samples are normalized by granite (L-70), which show strongly concave tetrad effects (Fig. 6a). The sulfide sample (L-71 sph-1) is normalized by granite (L-70) and skarn (L-63) samples, which display a concave tetrad effect and an octad effect, although such a tetrad or octad effect is not obvious in heavy REE (Fig. 6b).

$\mathrm{Y} / \mathrm{Ho}$ atomic weight ratios of granites in Lamo vary from 27.2 to 27.6. Sulfides show $\mathrm{Y} / \mathrm{Ho}$ ratios of 26.2 33.7. Skarns have $\mathrm{Y} / \mathrm{Ho}$ ratios of 26.3 28.9. All these ratios are close to the chondritic $\mathrm{Y} / \mathrm{Ho}$ ratio of 28 and fall within the charge-and-radius-controlled (CHARAC) fields (Bau, 1996). However, the fluorite sample has a higher $\mathrm{Y} / \mathrm{Ho}$ ratio of 79.7. Fractionation of $\mathrm{Y}-\mathrm{Ho}$ in hydrothermal fluorites can be related to the relative stabilities of $Y$ and REE fluorite complexes, which are higher for $Y$ than for Ho (Bau and Dulski, 1995).

\section{REE and $Y$ in sulfides from the Gaofeng deposit}

Concentrations of REE and Y of sulfides from the No. 100 orebody at Gaofeng are low in most samples. The total REE contents vary from 0.06 to $3.0 \mathrm{ppm}$ (Table 3 and Fig. 7). These sulfides can be divided into three groups based on their REE patterns. Group 1 includes G-25-Py, G-25-Sph, G-10-Py and G-10-Sph and shows light REE enrichment, large positive Eu anomalies $\left(\mathrm{Eu} / \mathrm{Eu}^{*}=\right.$ 1.8 11.4) and inconspicuous $\mathrm{Ce}$ anomalies $\left(\mathrm{Ce} / \mathrm{Ce}^{*}=\right.$ $0.8 \sim 1.0$ ) (Fig. 7a). Pyrite and sphalerite separated from the same ore (G-25 and G-10) have different REE abundances, but their REE patterns are similar. The concentrations of HREE (from Ho to $\mathrm{Lu}$ ) in the samples are so low that they are hardly detectable. Group 2 contains G18b-Sph, G-23a-Sph, G-24-Sph and G-24-Py and has lower total REE abundances $(0.06 \sim 0.4 \mathrm{ppm})$. They show large negative $\mathrm{Ce}$ anomalies $\left(\mathrm{Ce} / \mathrm{Ce}^{*}=0.2 \sim 0.5\right)$ and positive Eu anomalies $\left(\mathrm{Eu} / \mathrm{Eu}^{*}=1.4 \sim 3.6\right)$ (Fig. 7b). Group 3 includes G-9a-Sph and G-15a-Py. They show slightly LREE enrichment $($ LREE/HREE $=3.5)$ and small negative Eu anomalies $\left(\mathrm{Eu} / \mathrm{Eu}^{*}=0.8\right.$ and 0.9$)$ (Fig. 7c).

Contents of $\mathrm{Y}$ in sulfides from Gaofeng deposit vary 

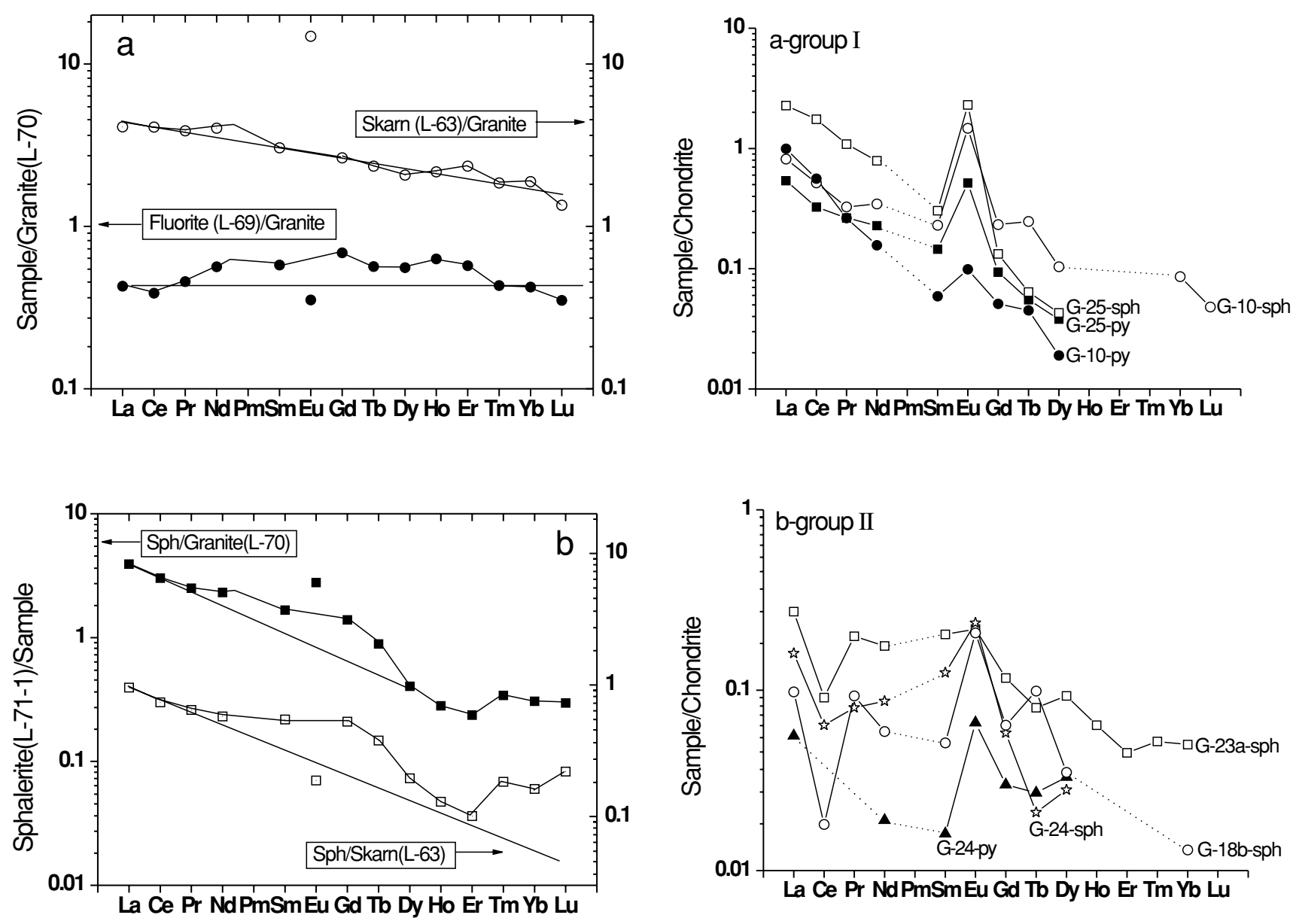

Fig. 6. Granite-normalized REE patterns of skarn and fluorite at Lamo (a), and Granite- or skarn-normalized REE patterns of sulfides at Lamo (b).

from 0.05 to $2.1 \mathrm{ppm}$. Ho concentrations were only detected in two samples. Therefore, only two Y/Ho ratios were acquired: G-9a-Sph with a Y/Ho ratio of 63 and G23a-Sph with a $\mathrm{Y} / \mathrm{Ho}$ ratio of 75 .

REE and $Y$ in sulfides from the Changpo-Tongkeng deposit

REE and Y contents in sulfides collected from the Changpo-Tongkeng stratiform orebodies are listed in Table 4 and shown in Fig. 8. The total REE abundances of the sulfides vary from 0.4 to $15.4 \mathrm{ppm}$, which are higher than that of the Gaofeng massive ores. As shown in Fig. 8, the REE patterns of sulfides from No. 91 orebody are appreciably different from those of sulfides from No. 92 orebody. The REE patterns of sulfide samples from orebody 91 are LREE-enriched (LREE/HREE = 6.1 20.2) with small or no negative $\mathrm{Eu}$ anomalies $\left(\mathrm{Eu} / \mathrm{Eu}^{*}=\right.$ 0.7 1.0) (Fig. 8a). Sulfide samples from orebody 92 have smaller LREE enrichments (LREE/HREE $=3.2 \sim 8.0$ ) but

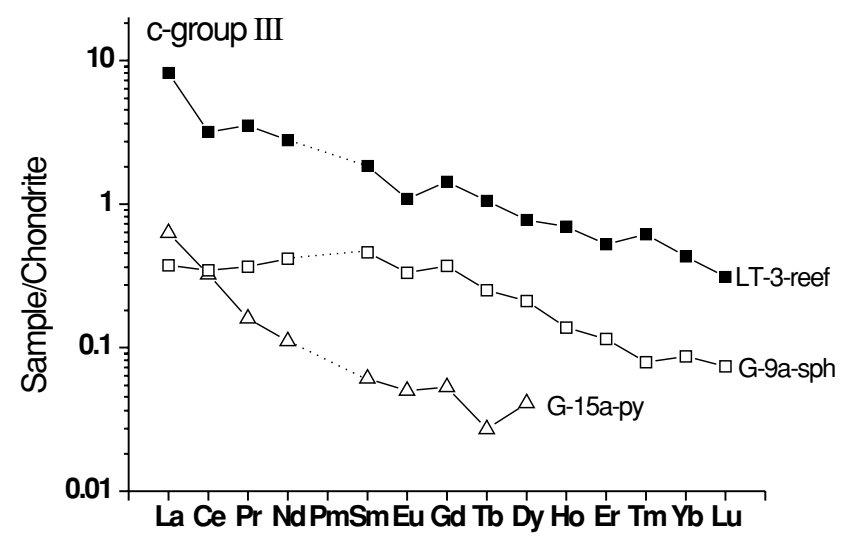

Fig. 7. Chondrite-normalized REE patterns of sulfides from the Gaofeng massive ores (LT-3-Reef, reef limestone, after Fan et al., 2004).

larger negative $\mathrm{Eu}$ anomalies $\left(\mathrm{Eu} / \mathrm{Eu}^{*}=0.5 \sim 0.7\right)$ than those from orebody 91 (Fig. 8b).

Figure 9 shows the REE concentration ratios between several pairs of sulfide samples. The sphalerite (T47-Sph1) sample is normalized by sphalerite (T47-sph-2) sam- 
Table 3. Rare earth element and Y compositions of sulfides from the Gaofeng massive sulfide deposit in the Dachang ore field (in ppm)

\begin{tabular}{|c|c|c|c|c|c|c|c|c|c|c|}
\hline & $\begin{array}{c}\text { G-9a-sph } \\
\text { Sph }\end{array}$ & $\begin{array}{c}\text { G-10-sph } \\
\text { Sph }\end{array}$ & $\begin{array}{c}\text { G-10-py } \\
\text { Py }\end{array}$ & $\begin{array}{c}\text { G15a-py } \\
\text { Py }\end{array}$ & $\begin{array}{c}\text { G18b-sph } \\
\text { Sph }\end{array}$ & $\begin{array}{c}\text { G23a-sph } \\
\text { Sph }\end{array}$ & $\begin{array}{c}\text { G24-sph } \\
\text { Sph }\end{array}$ & $\begin{array}{l}\text { G25b-sph } \\
\text { Sph }\end{array}$ & $\begin{array}{c}\text { G24-py } \\
\text { Py }\end{array}$ & $\begin{array}{c}\text { G25b-py } \\
\text { Py }\end{array}$ \\
\hline $\mathrm{La}$ & 0.12 & 0.25 & 0.31 & 0.2 & 0.03 & 0.09 & 0.05 & 0.17 & 0.02 & 0.71 \\
\hline $\mathrm{Ce}$ & 0.28 & 0.42 & 0.45 & 0.26 & 0.01 & 0.07 & 0.05 & 0.26 & b.d. & 1.41 \\
\hline $\operatorname{Pr}$ & 0.05 & 0.04 & 0.03 & 0.02 & 0.01 & 0.02 & 0.01 & 0.03 & b.d. & 0.13 \\
\hline $\mathrm{Nd}$ & 0.25 & 0.21 & 0.09 & 0.07 & 0.04 & 0.11 & 0.05 & 0.14 & 0.01 & 0.47 \\
\hline $\mathrm{Sm}$ & 0.09 & 0.05 & 0.01 & 0.01 & 0.01 & 0.04 & 0.02 & 0.03 & 0.003 & 0.06 \\
\hline $\mathrm{Eu}$ & 0.02 & 0.11 & 0.007 & 0.004 & 0.02 & 0.02 & 0.02 & 0.04 & 0.005 & 0.17 \\
\hline $\mathrm{Gd}$ & 0.1 & 0.06 & 0.01 & 0.01 & 0.02 & 0.03 & 0.02 & 0.02 & 0.008 & 0.04 \\
\hline $\mathrm{Tb}$ & 0.01 & 0.01 & 0.002 & 0.001 & 0.005 & 0.004 & 0.001 & 0.003 & 0.001 & 0.003 \\
\hline Dy & 0.07 & 0.03 & 0.006 & 0.01 & 0.01 & 0.03 & 0.01 & 0.01 & 0.01 & 0.01 \\
\hline Ho & 0.01 & b.d. & b.d. & b.d. & b.d. & 0.005 & b.d. & b.d. & b.d. & b.d. \\
\hline $\mathrm{Er}$ & 0.02 & b.d. & b.d. & b.d. & b.d. & 0.009 & b.d. & b.d. & b.d. & b.d. \\
\hline $\mathrm{Tm}$ & 0.003 & b.d. & b.d. & b.d. & b.d. & 0.002 & b.d. & b.d. & b.d. & b.d. \\
\hline $\mathrm{Yb}$ & 0.02 & 0.02 & b.d. & b.d. & 0.003 & 0.01 & b.d. & b.d. & b.d. & b.d. \\
\hline $\mathrm{Lu}$ & 0.002 & 0.002 & b.d. & b.d. & b.d. & b.d. & b.d. & b.d. & b.d. & b.d. \\
\hline $\mathrm{Y}$ & 0.62 & 1.42 & 0.71 & 0.5 & 0.1 & 0.35 & 0.05 & 0.09 & 2.1 & 0.18 \\
\hline$\Sigma$ REE & 1.0 & 1.2 & 0.9 & 0.6 & 0.2 & 0.4 & 0.2 & 0.7 & 0.06 & 3.0 \\
\hline LREE/HREE & 3.5 & & & & & 3.8 & & & & \\
\hline $\mathrm{Eu} / \mathrm{Eu}^{*}$ & 0.8 & 6.3 & 1.8 & 0.9 & 3.6 & 1.4 & 2.8 & 4.4 & 3.0 & 11.4 \\
\hline $\mathrm{Ce} / \mathrm{Ce}^{*}$ & 0.9 & 0.9 & 0.9 & 0.8 & 0.2 & 0.4 & 0.5 & 0.8 & & 1.0 \\
\hline $\mathrm{Y} / \mathrm{Ho}$ & 63 & & & & & 75 & & & & \\
\hline
\end{tabular}

b.d. = below detection .

Table 4. Rare earth element and Y compositions of sulfides from the Changpo-Tongkeng stratiform sulfide deposit in the Dachang ore field (in ppm)

\begin{tabular}{|c|c|c|c|c|c|c|c|c|c|c|}
\hline Orebodies & $\begin{array}{c}\text { T43-sph } \\
91\end{array}$ & $\begin{array}{c}\text { T44b-sph } \\
91\end{array}$ & $\begin{array}{c}\text { T45a-sph } \\
91\end{array}$ & $\begin{array}{c}\text { T47-sph-1 } \\
91\end{array}$ & $\begin{array}{c}\text { T47-sph-2 } \\
91\end{array}$ & $\begin{array}{c}\text { T33-py } \\
92\end{array}$ & $\begin{array}{c}\text { T36C-py } \\
92\end{array}$ & $\begin{array}{c}\text { T38-sph } \\
92\end{array}$ & $\begin{array}{c}\text { T38-py } \\
92\end{array}$ & $\begin{array}{c}\text { T57-py } \\
92\end{array}$ \\
\hline $\mathrm{La}$ & 0.48 & 0.17 & 2.91 & 2.01 & 0.87 & 0.37 & 0.06 & 0.06 & 0.16 & 1.535 \\
\hline $\mathrm{Ce}$ & 1.06 & 0.32 & 5.83 & 4.0 & 2.01 & 1.02 & 0.08 & 0.09 & 0.39 & 4.904 \\
\hline $\operatorname{Pr}$ & 0.12 & 0.04 & 0.73 & 0.35 & 0.2 & 0.17 & 0.02 & 0.02 & 0.08 & 0.694 \\
\hline $\mathrm{Nd}$ & 0.48 & 0.15 & 2.92 & 1.6 & 0.75 & 0.86 & 0.1 & 0.14 & 0.42 & 3.298 \\
\hline $\mathrm{Sm}$ & 0.10 & 0.03 & 0.67 & 0.23 & 0.13 & 0.18 & 0.02 & 0.04 & 0.11 & 0.728 \\
\hline $\mathrm{Eu}$ & 0.02 & 0.01 & 0.16 & 0.04 & 0.03 & 0.03 & 0.006 & 0.01 & 0.02 & 0.140 \\
\hline $\mathrm{Gd}$ & 0.08 & 0.02 & 0.61 & 0.17 & 0.09 & 0.2 & 0.03 & 0.04 & 0.12 & 0.618 \\
\hline $\mathrm{Tb}$ & 0.01 & 0.005 & 0.09 & 0.02 & 0.01 & 0.02 & 0.006 & 0.007 & 0.02 & 0.070 \\
\hline Dy & 0.07 & 0.02 & 0.62 & 0.12 & 0.06 & 0.14 & 0.03 & 0.04 & 0.09 & 0.381 \\
\hline Ho & 0.01 & 0.002 & 0.12 & 0.02 & 0.007 & 0.03 & 0.002 & 0.005 & 0.02 & 0.067 \\
\hline $\mathrm{Er}$ & 0.03 & 0.005 & 0.32 & 0.05 & 0.02 & 0.07 & 0.006 & 0.01 & 0.05 & 0.148 \\
\hline $\mathrm{Tm}$ & 0.004 & 0.001 & 0.04 & 0.006 & 0.002 & 0.01 & 0.000 & 0.001 & 0.006 & 0.015 \\
\hline $\mathrm{Yb}$ & 0.03 & 0.004 & 0.31 & 0.04 & 0.01 & 0.07 & 0.004 & 0.006 & 0.03 & 0.099 \\
\hline $\mathrm{Lu}$ & 0.002 & b.d. & 0.04 & 0.004 & b.d. & 0.01 & b.d. & b.d. & 0.003 & 0.012 \\
\hline $\mathrm{Y}$ & 0.5 & 0.24 & 3.48 & 1.06 & 0.37 & 0.93 & 0.29 & 0.23 & 0.73 & 2.092 \\
\hline$\Sigma \mathrm{REE}$ & 2.5 & 0.8 & 15.4 & 8.7 & 4.2 & 3.2 & 0.4 & 0.5 & 1.5 & 12.7 \\
\hline LREE/HREE & 9.6 & 12.9 & 6.1 & 19.1 & 20.2 & 4.8 & 3.7 & 3.2 & 3.4 & 8.0 \\
\hline $\mathrm{Eu} / \mathrm{Eu}^{*}$ & 0.7 & 1.0 & 0.8 & 0.7 & 0.8 & 0.5 & 0.7 & 0.7 & 0.5 & 0.6 \\
\hline $\mathrm{Ce} / \mathrm{Ce}^{*}$ & 1.0 & 0.9 & 0.9 & 1.1 & 1.1 & 1.0 & 0.6 & 0.6 & 0.9 & 1.1 \\
\hline Y/Ho & 40.7 & 129 & 28.4 & 57.1 & 51.9 & 34.5 & 134 & 48.3 & 39.7 & 31.1 \\
\hline
\end{tabular}

b.d. = below detection . 

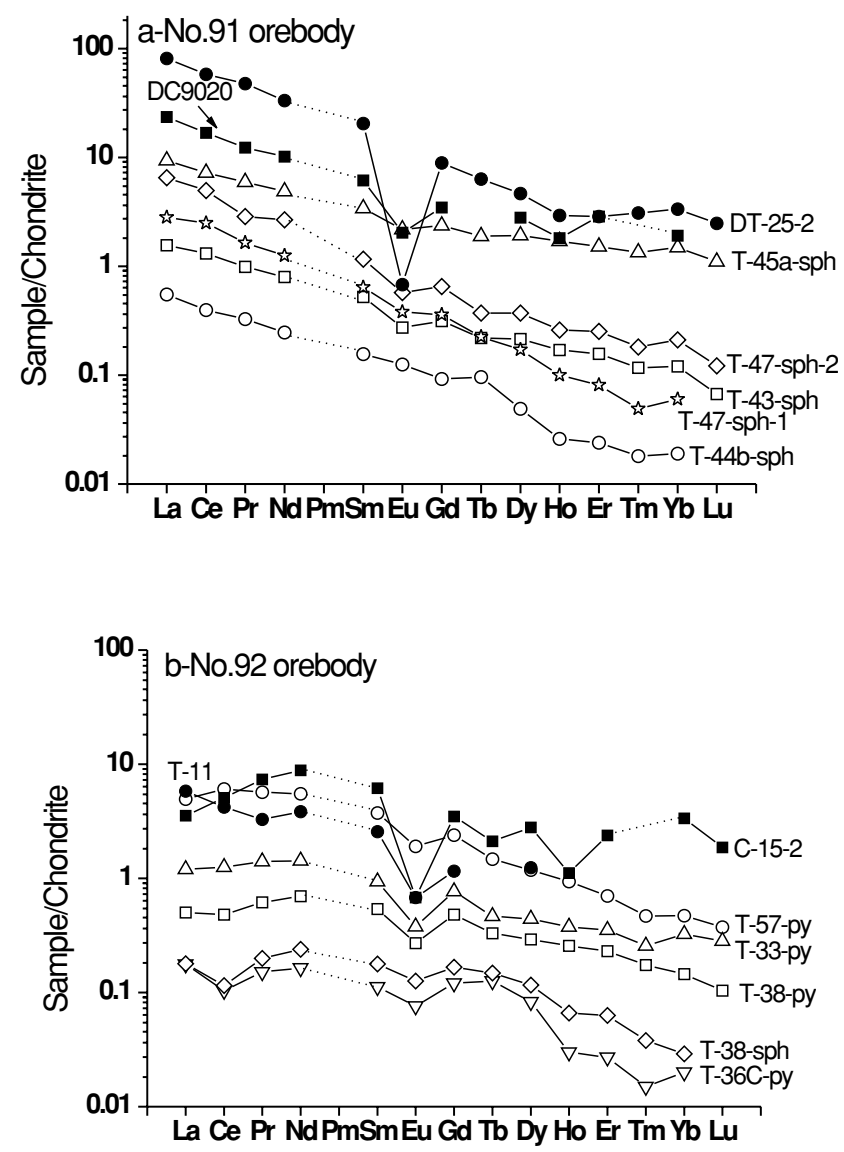

Fig. 8. Chondrite-normalized REE patterns of sulfides and host rocks from the No. 91 (a) and No. 92 (b) stratiform orebodies at Changpo-Tongkeng. The data for host rocks (DT25-2, DC9020, T11, C15-2, siliceous rock) came from Han et al. (1997).

ple from orebody 91, which indicate a concave tetrad effect (Fig. 9a). However, another sphalerite/sphalerite pair (T-43 sph and T-45a sph) shows a smooth variation trend without any significant tetrad effect (Fig. 9a). Figure 9b shows the REE concentration ratios for a pyrite/pyrite pair and a sphalerite/pyrite one without any significant tetrad effect, but both with a smooth variation trend in light and middle REEs.

$\mathrm{Y} / \mathrm{Ho}$ ratios of sulfides at Changpo-Tongkeng vary from 28.4 to 57.1 except for T-44b-Sph (129) and T-36cSph (134). It should be noted that the two samples with high Y/Ho ratios show similar Y concentrations but extremely lower Ho concentrations than others.

\section{Discussion}

Rare earth elements and $Y$ systematics of sulfides

REE are effective indicators of geochemical processes and are used with great success for petrogenetic studies
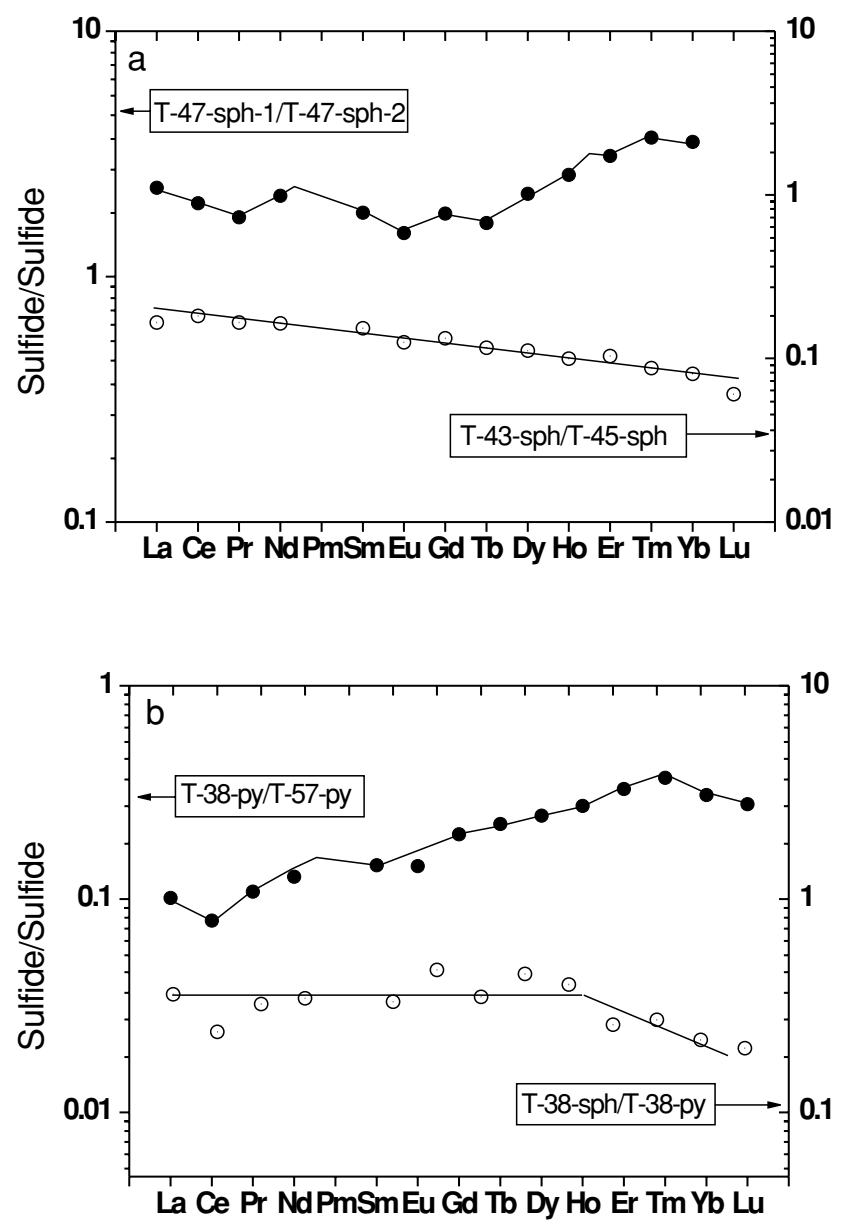

Fig. 9. Sulfide-normalized REE patterns of sphalerite (a) and pyrite (b) samples from Changpo-Tongkeng.

of igneous rocks. In contrast, the behavior of REE in hydrothermal systems is characterized by a general lack of consensus, reflecting the complexity of the processes invoked. Previous workers have carried out REE analyses of fluids emanating from active hydrothermal vents (Klinkhammer et al., 1994; Mitra et al., 1994; Bau and Dulski, 1999). REE analyses of hydrothermal precipitates have generally focused on Ca-bearing ore or gangue minerals, such as scheelite, fluorite and anhydrite (e.g., Bach et al., 2003; Bau et al., 2003). However, these minerals can be absent in ancient hydrothermal deposits. Therefore, a question arises about how to acquire information on the REE characteristics of ore-forming fluids in these deposits. Sulfide minerals may be good candidates to directly characterize the fluid chemistry in which these sulfides precipitated. Unfortunately, REE data of hydrothermal sulfides are rarely reported due to their low concentrations (Mills and Elderfield, 1995; Slack et al., 2000; Rimdkaya-Korsakova et al., 2003). Application of highresolution inductively coupled plasma mass spectrometry 
(HR-ICP-MS) can resolve this question. In this study, detection limits for REE and Y range from $0.1 \mathrm{ppt}$ to 3.2 ppt and blank values vary from 0.3 ppt to 10.6 ppt. REE and $Y$ contents of sulfides are generally higher than both detection limits and blank values and can be analyzed accurately.

REE and Y concentrations in sulfide crystals are controlled by the REE and Y compositions of the hydrothermal fluid from which sulfides precipitated and the partition coefficients between sulfides and the fluid. Apparently, few systematic laboratory studies of REE partitioning between solutions and hydrothermal minerals have been made. The REE and Y not only substitute in the crystal lattices of host minerals by replacing the main ions, but also may be trapped in fluid inclusions that represent the mineralizing fluid. The distribution of the REE into Ca-bearing hydrothermal minerals, such as scheelite, anhydrite and fluorite, may be crystallographically controlled by replacement of the $\mathrm{Ca}^{2+}$ except for $\mathrm{Eu}^{2+}$ (Morgan and Wandless, 1980; Mills and Elderfield, 1995). Therefore, these minerals generally contain high abundance of REE and Y. However, regarding the substitution by REE and $\mathrm{Y}$ in crystal lattices of sphalerite and pyrite, replacement of the $\mathrm{Zn}^{2+}$ and $\mathrm{Fe}^{2+}$ ions is much more difficult than $\mathrm{Ca}$ in $\mathrm{Ca}$-bearing minerals, and it may be assumed that part of the REE-Y contents in the sulfide minerals may come from fluid inclusions and crystal defects. Therefore, we suggest that the REE patterns of sulfides likely reflect the REE patterns of their parent solutions. Sulfides from the active TAG black and white smoker chimneys have low REE contents with a LREE-enriched pattern and a positive Eu anomaly. It has been demonstrated that the REE patterns in these sulfides resemble the patterns of the hydrothermal fluids (Mills and Elderfield, 1995). Marques et al. (2006) also demonstrated that REE patterns of sulfides from the Rainbow hydrothermal field, Mid-Atlantic Ridge clearly reflect the vent fluid REE pattern with significant LREE enrichment and positive Eu anomaly.

\section{Magmatic hydrothermal fluids at Lamo}

There is little argument against the skarn origin for the Lamo orebody as it has many of the characteristics of the typical proximal calcic skarns (Fu et al., 1993). Fu et al. (1993) recognized four mineral stages at Lamo: (1) garnet-vesuvianite-wollastonite(-diopside); (2) fluoritequartz-epidote(-amphibole); (3) biotite-sericitechalcopyrite-sphalerite-arsenopyrite-pyrrhotite; (4) chlorite-carbonates-galena-stibnite. This mineralization sequence is strikingly similar in many granite-related replacement deposits around the world. Fluid inclusion studies indicate high formational temperatures $\left(450 \sim 600^{\circ} \mathrm{C}\right)$ and salinities ( $>35$ equiv. wt. $\% \mathrm{NaCl}$ ) for the mineralizing fluid (Fu et al., 1993). Isotope studies also implied that ore-forming fluid was exsolved from the Longxianggai granite magma (Fu et al., 1991). The analysis of REE in sulfides and granites provides an opportunity to model the REE behavior in the fluid-melt system.

As shown in Fig. 5a, the Longxianggai granite shows slightly LREE-enriched pattern with negative Eu anomalies. The REE pattern is the same as those previously reported (Pan et al., 1993). This type of REE distribution pattern is very common and very similar to other tin granites around the world. The sulfides have more abundant REE contents and are more LREE-enriched than the granite (Fig. 5b). These data suggest mobility of REE in magmatic-hydrothermal fluid system. The fluid exsolved from granitic magma is more enriched in LREE than the magma. There is a slightly alteration of Eu anomaly between the magma and the fluid. These conclusions are accordant with previous studies (e.g., Banks et al., 1994).

The skarn samples share similar REE patterns as those sulfides, but their total REE abundances are higher than the sulfides (Fig. 5b). Skarns show slightly LREE-enriched and concave tetrad effects when normalized by granite (Fig. 6a). These REE characteristics of skarns may reflect an intensive fluid/rock interaction between magmatic hydrothermal fluid and limestones. Fluorite sample shows flat and slightly middle-REE enrichment and concave tetrad effects when normalized by granite (Fig. 6a). However, the sulfides show strong LREE enrichment and concave tetrad effects when normalized either by granite or by skarn (Fig. 6b). The difference in these REE characteristics may suggest their different complexing and changes of the environment of REEs from an ionic bond to a covalent one or vice versa. According to Wood (1990), the presence of fluorite, as is observed and analyzed in our studied granite, indicates that fluorine was the most important complexing agent of the magmatic-hydrothermal fluids (Irber, 1999).

\section{Exhalative hydrothermal fluids responsible for massive and stratiform mineralization}

In the Changpo-Tongkeng deposits, both stratiform and vein-type ores occur, but there is no development of skarn minerals. The fine-bedded siliceous rocks, tourmalines, and K-feldspar rocks are interbedded with cassiterite-sulfide ores. Fu et al. (1993) interpreted these rocks or minerals as hydrothermal alteration. However, there are several lines of evidence that contradict this interpretation. Pan et al. (1993) studied the K-feldspars and anorthites associated with bedded cassiterite-sulfides ores and suggested an authigenic origin for them. Han et al. (1993) found that some of the K-feldspars in stratiform and massive ores are adularia or hyalophane, and favored a sedimentary exhalative-diagenetic origin. Jiang et al. (1999) also studied the chemical and $\mathrm{Rb}-\mathrm{Sr}, \mathrm{Sm}-\mathrm{Nd}$ isotopic systematics of tourmaline from the Dachang deposit. 


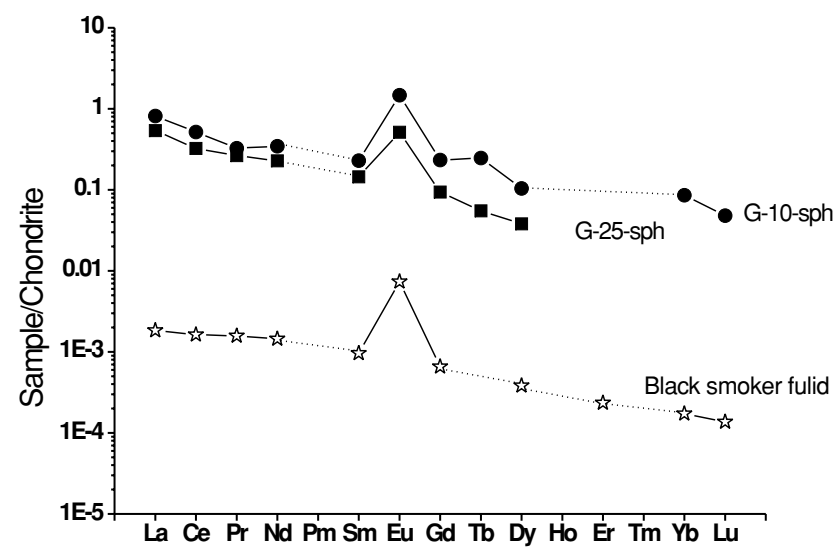

Fig. 10. Comparison of the REE distributions of the Gaofeng massive sulfides and modern submarine black smoker fluid (from Mitra et al., 1994).

They found that tourmalines from the bedded ores and host rocks have distinct geochemical characteristics in common with those from quartz-tourmaline veins in the nearby Longxianggai granite. These data do not support a skarn or replacement-type origin for the stratiform and massive ores.

Our data show that the sulfide samples from the Changpo-Tongkeng and Gaofeng deposits have much lower REE concentrations relative to the Lamo sulfides. It indicates that REEs in these deposits might be derived from different sources. In general, magmatic-hydrothermal fluids have relatively high REE contents. However, concentrations of REEs in modern submarine hydrothermal fluids are typically very low (e.g., Klinkhammer $e t$ al., 1994). Most of the massive sulfide samples from the Gaofeng deposit display LREE enrichments and positive $\mathrm{Eu}$ anomalies on chondrite-normalized plots (Figs. 7a and $7 \mathrm{~b})$. The REE patterns of sulfides from the Gaofeng massive ores are very different from those of the Lamo deposit. LREE enrichments and positive Eu anomalies are characteristic of both ancient and modern exhalative hydrothermal system. End member hydrothermal fluids at active black smoker vents have enriched REE concentrations $(10 \sim 10,000 \times$ seawater concentrations $)$ and chondrite normalized REE patterns with a large positive $\mathrm{Eu}$ anomaly, no Ce anomaly, and enrichment in the LREE compared to the HREE (Klinkhammer et al., 1994; Mitra et al., 1994; Bau and Dulski, 1999). Massive sulfides, anhydrites, barites and oxides collected on the sea floor, such as those from the Red Sea, the Southern Explorer Ridge, the East Pacific Rise, Middle Valley on the Juan de Fuca Ridge and TAG, also show positive Eu anomalies and LREE-enriched patterns (Barrett et al., 1990; Krasnov et al., 1994; Mills and Elderfield, 1995; German et al., 1999; Bach et al., 2003). Positive Eu anoma-

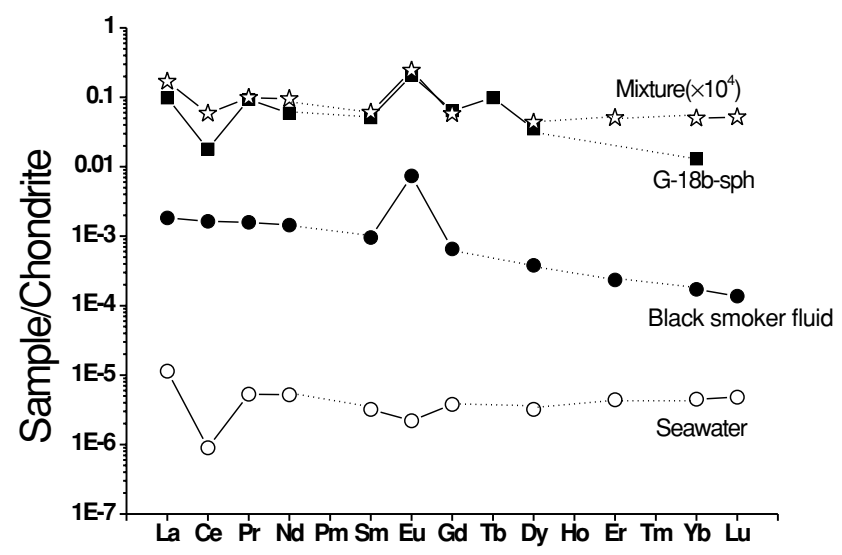

Fig. 11. Comparison of the REE distributions of the Gaofeng massive sulfides and a model calculation for a mixture of $99.7 \%$ seawater and $0.3 \%$ black smoker fluid.

lies are reported in some samples of massive sulfides from ancient massive sulfide deposits, such as the Bathurst district of New Brunswick, Broken Hill in Australia, Sullivan in British Columbia, Kuroko in Japan and so on (Lottermoser, 1989; Jiang et al., 2000; Slack et al., 2000; Terakado and Walker, 2005). The LREE-enrichments and positive Eu anomalies of both ancient and modern exhalative hydrothermal systems are generally attributed to high-temperature $\left(>250^{\circ} \mathrm{C}\right)$ processes and the leaching of plagioclase-rich lithologies at depth by circulating seawater-derived hydrothermal fluids (Sverjensky, 1984; Slack et al., 2000). The REE patterns of G-25 and G-10 from the massive sulfide ores at Gaofeng may resemble the black smoker fluid patterns (Fig. 10).

Several massive sulfide samples display pronounced negative $\mathrm{Ce}$ anomalies on chondrite normalized REE plots (Fig. 7b). Total REE abundances of these samples are lower than those without negative $\mathrm{Ce}$ anomalies. Negative Ce anomalies appear to be common in modern submarine hydrothermal systems. Barrett et al. (1990) firstly reported several massive sulfide-sulfate samples from the Southern Explorer Ridge, which have relatively flat REE patterns with positive Eu anomalies and negative $\mathrm{Ce}$ anomalies. Such REE patterns are also found in massive sulfides from Middle Valley on the Juan de Fuca Ridge (Krasnov et al., 1994) and oxides from the TAG mound (Mills and Elderfield, 1995). Analysis of hydrothermal plume particles has shown that the particles close to an active vent-field exhibit REE patterns of both seawater and vent-fluid characteristics (i.e., negative Ce anomalies and positive Eu anomalies), whereas at increasing dispersion, seawater characteristics become dominant (German et al., 1999). The negative Ce anomalies in modern sulfide and oxide samples are best interpreted as resulting from variable mixtures of hydrothermal fluid 


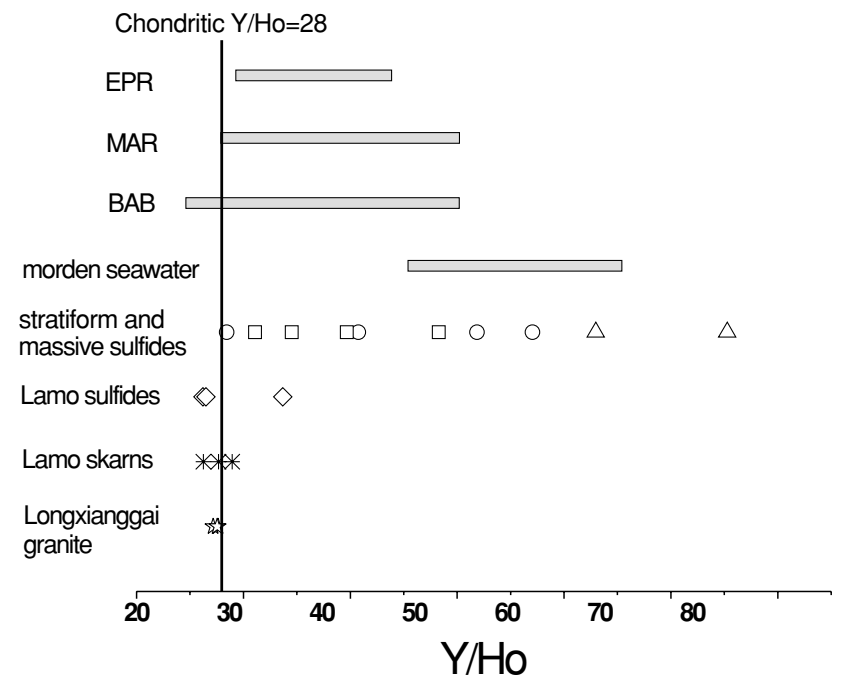

Fig. 12. Y/Ho ratios of sulfides from Dachang, modern hydrothermal fluids and seawater. Y/Ho data of Modern seawater, $B A B$ (Back-Arc Basin), MAR (Middle-Atlantic ridge) and EPR (East Pacific Ridge) hydrothermal fluids are from Bau and Dulski (1999), and Douville et al. (1999).

and seawater (Barrett et al., 1990; Mills and Elderfield, 1995; German et al., 1999), based on the large negative Ce anomaly observed in seawater (Elderfield and Greaves, 1982). This model is favored for the Gaofeng massive sulfides. A model calculation is illustrated in Fig. 11, where a sample with a positive Eu anomaly and negative Ce anomaly (G-18b-Sph) is compared to a calculated pattern for a mixture of $99.7 \%$ seawater and $0.3 \%$ black smoker end-member fluid. As can be seen in Fig. 11, the two patterns show a reasonable agreement. Similar models were also used to interpret the REE pattern of some massive sulfide ores on the Southern Explore Ridge (Barrett et al., 1990) and TAG chimney oxides (Mills and Elderfield, 1995). Two samples (G-9a-Sph and G-15aSph) from Gaofeng display REE patterns with a slightly negative Eu anomaly (Fig. 7c), which are similar to that of the host rock (reef limestone, LT-3-Reef also shown in Fig. 7c). The REE patterns in these two sulfides may reflect fluid interacting with the host reef limestone or fluid mixing with circulating pore fluid in the reef limestone.

However, sulfides from the stratiform orebodies at Changpo-Tongkeng display distinctly different REE patterns from those of the massive sulfides at Gaofeng. REE patterns of the sulfides from No. 91 orebody are also slightly different from those of the sulfides from No. 92 orebody (Fig. 8), but their REE patterns are similar to the host rocks, although with smaller negative Eu anomalies. Since the magmatic hydrothermal fluid and the sediment show more negative Eu anomalies, we suggest that magmatic-hydrothermal replacement may not be the cause for sulfides with these REE patterns. In fact, Lottermoser (1989) found that exhalites associated with the Broken Hill deposit show variable REE patterns from positive to negative Eu anomalies. Exhalites associated with massive sulfide mineralization at the Pinnacles deposit also have variable REE distributions, which change systematically both laterally and vertically within the stratigraphic column (Parr, 1992). Such variations suggest that there are chemical controls (e.g., Eh, pH and temperature) of REE concentrations in precipitating exhalites, as these parameters changed temporally as well as spatially (Parr, 1992). If a hydrothermal fluid vents out onto the sea floor, the REE pattern of the fluid will be modified depending on the degree of mixing with seawater, the length of time of exposure to the seawater and the physical-chemical environments (e.g., the degree of subaqueous oxidation, $\mathrm{pH}$ and temperature). Thus, sulfides and siliceous rocks are suggested to be synsedimentary in origin. It is likely that the hydrothermal fluids exhaled onto the sea floor to form a metal-rich brine pool or a hydrothermal plume, and then metal sulfides precipitated alternately with siliceous rocks to form stratiform sulfide mineralization.

Y/Ho ratio as a tracer for the origin of ore-forming fluids

Yttrium and REE are physicochemically very similar, all being trivalent and showing similar ionic radii and electronegativities. The closest similarity exists between $\mathrm{Y}$ and Ho, which show identical valencies and very similar ionic radii. In VIII-fold coordination, $\mathrm{Y}^{3+}$ and $\mathrm{Ho}^{3+}$ have ionic radii of $1.019 \AA$ and $1.015 \AA$, respectively (Shannon, 1976). The geochemical twins Y and Ho remain tightly coupled in many geochemical processes, leading to the maintenance of the chondritic $\mathrm{Y} / \mathrm{Ho}$ atomic weight ratio of 28 in most igneous rocks and clastic sediments (Bau, 1996, and reference therein). In contrast, aqueous fluids and their precipitates are often characterized by non-chondritic Y/Ho ratios. Modern Pacific seawater displays $\mathrm{Y} / \mathrm{Ho}$ ratios between 46 and 65 (Nozaki et al., 1997). These ratios are significantly higher than those of chondrites and shales. Recent data for the submarine hydrothermal fluids show that the hydrothermal fluids display variable Y/Ho ratios from 25 to 50 (Bau and Dulski, 1999; Douville et al., 1999). High Y/Ho ratios of the fluids could be due to the circulation of seawater or a mixing of hydrothermal fluid with seawater.

The Y/Ho ratios of sulfides from different types of mineralization, modern seawater and active hydrothermal fluids are compared in Fig. 12. The granites, skarns and the sulfides from the Lamo deposit all show near chondritic $\mathrm{Y} / \mathrm{Ho}$ ratios. However, the sulfides from stratiform and massive orebodies display variable $\mathrm{Y} / \mathrm{Ho}$ ratios from 28 to 75 , similar to the modern seawater and hydrothermal fluids. The super-chondritic Y/Ho ratios 


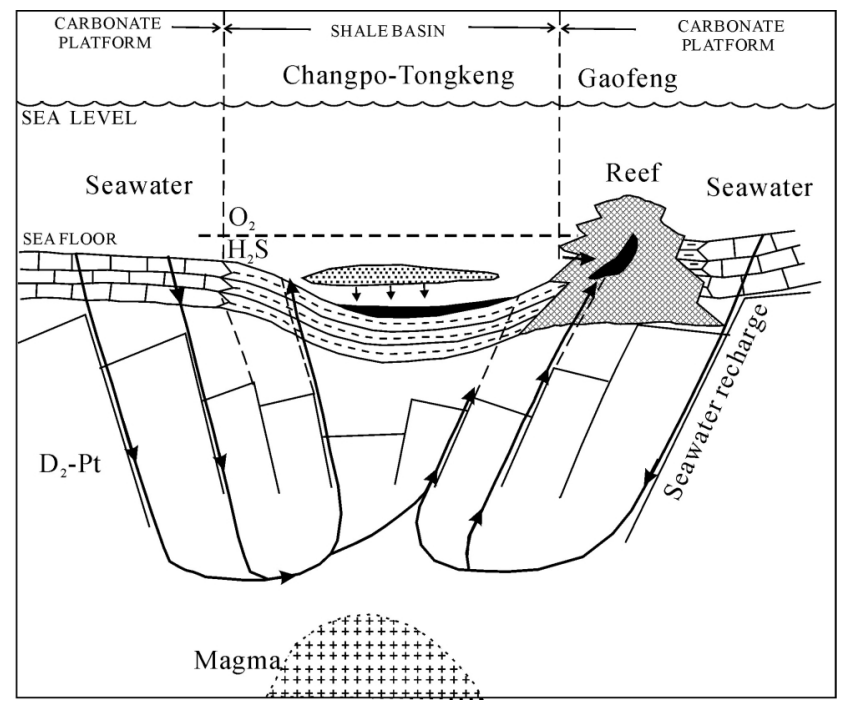

Fig. 13. Carton showing a genetic model of Changpo-Tongkeng stratiform and Gaofeng massive sulfide deposits at Dachang.

may be caused by the involvement of seawater during the ore-forming process. The $\mathrm{Y} / \mathrm{Ho}$ ratios provide new evidence favoring a submarine exhalative-hydrothermal origin of the stratiform and massive ores at Dachang.

\section{Ore forming processes in the Dachang ore field}

The ore deposits in the Dachang ore field may have formed by multiple stages of mineralization including Devonian submarine hydrothermal processes as well as Cretaceous magmatic-hydrothermal processes. The former ones account for the massive and bedded ore formation, and the latter ones were responsible for skarntype and some vein-type ore formation. The region of the Dachang ore field was a passive continental margin for much of its history. After the Jinning movement, sedimentary strata of Late Sinian to Ordovician age were deposited along the shelf of Yangtze platform. These beds contain many economically valuable elements, such as $\mathrm{Sn}, \mathrm{Sb}, \mathrm{Cu}, \mathrm{Pb}$ and $\mathrm{Zn}$, and were probably the main source for mineralization in the region (Chen, 1988; Chen et al., 1993). During the Late Devonian, under the effect of the action of the Paleo-Tethys tectonics, seawater circulation occurred in the third order deep-water troughs. The convectively circulated seawater leached Sn and other metals from the older sedimentary rocks. Although the carbonates in the Middle Devonian $\left(\mathrm{D}_{2}\right)$ suggest a shallow sea platform setting, the siliceous rocks and black shales in the Upper Devonian $\left(\mathrm{D}_{3}\right)$ may indicate a local trough setting with much deep water depths, and the syn-sedimentary exhalative-hydrothermal ore-forming processes occurred at Dachang during this period. It should be noted that the submarine hydrothermal activity developed at
Dachang is not comparable to those we observe in modern mid-ocean ridge systems, but may be analogous to those proposed for the syn-sedimentary massive and bedded sulfide ores at Sullivan deposits in British Columbia, Canada (Campbell et al., 1980; Jiang et al., 2000; Slack et al., 2000). It is speculated that at Changpo-Tongkeng, hydrothermal fluids may have migrated upward and discharged into the seafloor to form a brine pool and stratiform sulfides might precipitate from this brine pool, or that the hydrothermal fluids produced sub-seafloor synsedimentary replacement mineralization within the clastic sediment layers near to the seawater-sediment interface during Late Devonian period. At Gaofeng, submarine hydrothermal fluids might have transported metals into the cavity in the Middle Devonian reef limestone along cracks and then precipitated massive sulfide ores via hydrothermal replacement of host limestone. A general genetic model for the syn-sedimentary exhalativehydrothermal and replacement ore formation during Late Devonian is summarized in Fig. 13. In the late-Yanshanian era, the Longxianggai granite intruded at Lamo and hydrothermal fluids that exsolved from the magma formed the skarn ores and vein-type ores.

\section{CONClusions}

Sulfides from the Lamo deposit display high total REE abundance with LREE-enriched patterns and pronounced negative $\mathrm{Eu}$ anomalies, which indicate the responsible mineralizing fluid being of magmatic hydrothermal origin. However, most sulfides from the Gaofeng massive sulfide orebody display very low total REE abundance with LREE enrichments and large positive Eu anomalies, which are similar to that of the modern submarine hydrothermal fluids and are in favor of an exhalative hydrothermal origin for the massive ores. Some of the sulfide samples show large negative $\mathrm{Ce}$ anomalies and are interpreted as resulting from variable mixtures of hydrothermal fluid and seawater. Sulfides from stratiform orebodies at Changpo-Tongkeng are LREE-enriched with small or no negative Eu anomalies. Their REE patterns are similar to their host rocks, which may indicate that the sulfides and their host rocks are syn-sedimentary in origin and their REE patterns are controlled by the local physicalchemical environments (e.g., $f \mathrm{O}_{2}, \mathrm{pH}$ and temperature) which changed temporally as well as spatially. Thus, the ore-forming fluids responsible for mineralization of the stratiform and massive ores are most likely of exhalative hydrothermal origin. Differences in local mineralizing environments lead to different REE patterns of sulfides. $\mathrm{Y} / \mathrm{Ho}$ ratios of sulfides also support this genetic model. In summary, we suggest that the REE and Y of sulfides is a useful geochemical tool for tracing the origin of sulfide mineralization, especially for massive sulfide deposits. 
Acknowledgments-Financial supports for this study were provided by China National Science Foundation Project (No. 40221301). This paper benefited from thoughtful reviews and constructive comments by Editor. Tasuku Akagi, Dr. Iwao Kawabe, Dr. Martin Palmer, and one anonymous reviewer.

\section{REFERENCES}

Allen, D. E. and Seyfried, W. E., Jr. (2005) REE controls in ultramafic hosted MOR hydrothermal systems: An experimental study at elevated temperature and pressure. Geochim. Cosmochim. Acta 69, 675-683.

Bach, W., Roberts, S., Vanko, D. A., Binns, R. A., Yeats, C. J., Craddock, P. R. and Humphris, S. E. (2003) Controls of fluid chemistry and complexation on rare-earth element contents of anhydrite from the Pacmanus subseafloor hydrothermal system, Manus Basin, Papua New Guinea. Mineral. Deposit. 38, 916-935.

Banks, D. A., Yardley, B. W. D., Campbell, A. R. and Jarvis, K. E. (1994) REE composition of an aqueous magmatic fluid: a fluid inclusion study from the Capitan Pluton, New Mexico, U.S.A. Chem. Geol. 113, 259-272.

Barrett, T. J., Jarvis, I. and Jarvis, K. E. (1990) Rare earth element geochemistry of massive sulfides-sulfate and gossans on the Southern Explorer Ridge. Geology 18, 583-586.

Bau, M. (1996) Controls on the fractionation of isovalent trace elements in magmatic and aqueous systems: evidence from $\mathrm{Y} / \mathrm{Ho}, \mathrm{Zr} / \mathrm{Hf}$, and lanthanide tetrad effect. Contrib. Mineral. Petrol. 123, 323-333.

Bau, M. and Dulski, P. (1995) Comparative study of yttrium and rare-earth element behaviors in fluorite-rich hydrothermal fluids. Contrib. Mineral. Petrol. 119, 213-223.

Bau, M. and Dulski, P. (1999) Comparing yttrium and rare earths in hydrothermal fluids from the Mid-Atlantic Ridge: implications for $\mathrm{Y}$ and REE behavior during near-vent mixing and for the Y/Ho ratio of Proterozoic seawater. Chem. Geol. 155, 77-90.

Bau, M., Romer, R. L., Lüders, V. and Dulski, P. (2003) Tracing element sources of hydrothermal mineral deposits: REE and $\mathrm{Y}$ distribution and $\mathrm{Sr}-\mathrm{Nd}-\mathrm{Pb}$ isotopes in fluorite from MVT deposits in the Pennine Orefield, England. Mineral. Deposit. 38, 992-1008.

Boynton, W. V. (1984) Geochemistry of the rare earth elements: meteorite studies. Rare Earth Element Geochemistry (Henderson, P., ed.), 63-114, Elservier, Amsterdam.

Campbell, F. A., Ethier, V. G. and Krouse, H. R. (1980) The massive sulfide zone: Sullivan orebody. Econ. Geol. 75, 916-926.

Chen, H. D. (1988) Evolution of the Danchi late Paleozoic basin in Guangxi and its ore control mechanism. J. Chengdu College of Geology 15, 68-78 (in Chinese with English abstract).

Chen, Y. C., Huang, M. Z., Xu, J., Hu, Y. Z., Tang, S. H., Li, Y. Q. and Meng, L. K. (1993) Tin Deposits of Dachang. Geological Publishing House, Beijing, 361 pp. (in Chinese with English abstract).

Douville, E., Bienvenu, P., Charlou, J. I., Donval, J. P., Fouquet, Y., Appriou, P. and Gamo, T. (1999) Yttrium and rare earth elements in fluids from various deep-sea hydrothermal sys- tems. Geochim. Cosmochim. Acta 63, 627-643.

Elderfield, H. and Greaves, M. J. (1982) The rare earth elements in seawater. Nature 296, 214-219.

Fan, D. L., Zhang, T., Ye, J., Pašava, J., Kribek, B., Dobes, P., Varrin, I. and Zak, K. (2004) Geochemistry and origin of tin-polymetallic sulfide deposits hosted by the Devonian black shale series near Dachang, Guangxi, China. Ore Geol. Rev. 24, 103-120.

Fu, M., Changkakoti, A., Krouse, H. R., Gray, J. and Kwak, T. A. P. (1991) An oxygen, hydrogen, sulfur, and carbon isotope study of carbonate-replacement (skarn) tin deposits of the Dachang tin field, China. Econ. Geol. 86, 1683-1703.

Fu, M., Kwak, T. A. P. and Mernagh, T. P. (1993) Fluid inclusion studies of zoning in the Dachang tin-polymetallic ore field, People's Republic of China. Econ. Geol. 88, 283-300.

Gao, J. F., Lu, J. J., Lai, M. Y., Lin, Y. P. and Pu, W. (2003) Analysis of trace elements in rock samples using HRICPMS. J. Nanjing Univ. (Nat. Sci.) 39(6), 844-850.

German, C. R., Hergt, J., Palmer, M. R. and Edmond, J. M. (1999) Geochemistry of a hydrothermal sediment core from the OBS vent-field, $21^{\circ} \mathrm{N}$ East Pacific Rise. Chem. Geol. 155, 65-75.

Han, F., Shen, J. Z. and Hutchinson, R. W. (1993) Adulariaan important indicator mineral of syngenetic origin for stratiform mineralization at the Dachang tin-polymetallic deposit. Mineral Deposits (Beijing) 12(4), 330-337 (in Chinese with English abstract).

Han, F., Zhao, R. S., Shen, J. Z., Hutchinson, R. W., Jiang, S. Y. and Chen, H. D. (1997) Geology and Origin of Ores in the Dachang Tin-polymetallic Ore Field. Geological Publishing House, Beijing, 213 pp. (in Chinese with English abstract).

Heinrich, C. A. (1990) The chemistry of hydrothermal tin (tungsten) ore deposits. Econ. Geol. 85, 457-481.

Irber, W. (1999) The lanthanide tetrad effect and its correlation with $\mathrm{K} / \mathrm{Rb}, \mathrm{Eu} / \mathrm{Eu}{ }^{*}, \mathrm{Sr} / \mathrm{Eu}, \mathrm{Y} / \mathrm{Ho}$, and $\mathrm{Zr} / \mathrm{Hf}$ of evolving peraluminous granite suites. Geochim. Cosmochim. Acta $\mathbf{6 3}$, 489-508.

Jiang, S. Y., Han, F., Shen, J. Z. and Palmer, M. R. (1999) Chemical and $\mathrm{Rb}-\mathrm{Sr}, \mathrm{Sm}-\mathrm{Nd}$ isotopic systematics of tourmaline from the Dachang Sn-polymetallic ore deposit, Guangxi Province, P.R. China. Chem. Geol. 157, 49-67.

Jiang, S. Y., Slack, J. F. and Palmer, M. R. (2000) Sm-Nd dating of the giant Sullivan $\mathrm{Pb}-\mathrm{Zn}-\mathrm{Ag}$ deposit, British Columbia. Geology 28, 751-754.

Klinkhammer, G., Elderfield, H., Edmond, J. M. and Mitra, A. (1994) Geochemical implications of rare earth element patterns in hydrothermal fluids from mid-ocean ridges. Geochim. Cosmochim. Acta 58, 5105-5113.

Krasnov, S., Stepanova, T. and Stepanov, M. (1994) Chemical composition and formation of a massive sulfide deposit, Middle Valley, northern Juan de Fuca Ridge (Site 856). Proc. Ocean Drilling Prog., Sci. Res., Middle Valley Area, Northeast Pacific Ocean: College Station, Texas (Mottl, M. J., Davis, E. E., Fisher, A. T. and Slack, J. F., eds.), Ocean Drilling Program 139, 353-372.

Lottermoser, B. G. (1989) Rare earth element study of exhalites within the Willyama Supergroup, Broken Hill Block, Australia. Mineral. Deposit. 24, 92-99. 
Marques, A. F. A., Barriga, F. C., Chavagnac, V. and Fouquet, Y. (2006) Mineralogy, geochemistry, and Nd isotope composition of the Rainbow hydrothermal field, Mid-Atlantic Ridge. Mineral. Deposit. 41, 52-67.

Mills, R. A. and Elderfield, H. (1995) Rare earth element geochemistry of hydrothermal deposits from the active TAG Mond, $26^{\circ} \mathrm{N}$ Mid-Atlantic Ridge. Geochim. Cosmochim. Acta 59, 3511-3524.

Mitra, A., Elderfield, H. and Greaves, M. J. (1994) Rare earth elements in submarine hydrothermal fluids and plumes from the Mid-Atlantic Ridge. Mar. Chem. 46, 217-236.

Morgan, J. W. and Wandless, G. A. (1980) Rare earth element distribution in some hydrothermal minerals: evidence for crystallographic control. Geochim. Cosmochim. Acta 44, 973-980.

Nozaki, Y., Zhang, J. and Amakawa, H. (1997) The fractionation between $\mathrm{Y}$ and Ho in the marine environment. Earth Planet. Sci. Lett. 148, 329-340.

Pan, J., Amstutz, G. C. and Moh, G. (1993) Stratabound anorthites in the Dachang Sn-polymetallic ore field, Guangxi, China. Chinese J. Geochem. 12, 261-269.

Parr, J. M. (1992) Rare-earth element distribution in exhalites associated with Broken Hill-type mineralization at the Pinnacles deposit, New South Wales, Australia. Chem. Geol. 100, 73-91.

Petersen, E. U. (1986) Tin in volcanogenic massive sulfide deposits: an example from the Geco mine, Manitouwadge district, Ontario, Canada. Econ. Geol. 81, 323-342.

Rimdkaya-Korsakova, N. M., Dubinin, A. V. and Ivanov, V. M. (2003) Determination of rare-earth elements in sulfide minerals by inductively coupled plasma mass spectrometry with ion-exchange preconcentration. J. Anal. Chem. 58, 870-874.

Shannon, R. D. (1976) Revised effective ionic radii and sys- tematic studies of inter-atomic distances in halides and chalcogenides. Acta Cryst. A32, 751-767.

Slack, J. F., Meier, A. L., Malcolm, M. J., Fey, D. L., Doughten, M. W. and Wandless, G. A. (2000) Trace element and rareearth element geochemistry of bedded and massive sulphides from the Sullivan $\mathrm{Pb}-\mathrm{Zn}-\mathrm{Ag}$ Deposit, British Columbia-a reconnaissance study. The Geological Environment of the Sullivan Deposit, B.C (Lydon, J. W., Hoy, T., Slack, J. F. and Knapp, M. E., eds.), 720-735.

Sverjensky, D. A. (1984) Europium redox equlibria in aqueous solution. Earth Planet. Sci. Lett. 67, 70-78.

Terakado, Y. and Walker, R. J. (2005) Nd, Sr and Pb isotopic and REE geochemistry study of some Miocene submarine hydrothermal deposit (Kuroko deposits) in Japan. Contrib. Mineral. Petrol. 149, 388-399.

Wood, S. A. (1990) The aqueous geochemistry of the rare-earth elements and yttrium. 2. Theoretical predictions of speciation in hydrothermal solutions to $350^{\circ} \mathrm{C}$ at saturation water vapor pressure. Chem. Geol. 88, 99-125.

$\mathrm{Xu}$, W. X. (1987) Isotope geochemical study of the Dachang tin-polymetallic ore field. Proc. Internat. Symp. Geol. Tin Deposits, 156-164, Geological Publishing House, Beijing (in Chinese).

Zhao, K. D., Jiang, S. Y., Xiao, H. Q. and Ni, P. (2002) Origin of ore-forming fluids of the Dachang Sn-polymetallic ore deposit: Evidence from helium isotopes. Chinese Sci. Bull. 47(12), 1041-1045.

Zhao, K. D., Jiang, S. Y., Ni, P., Ling, H. F. and Jiang, Y. H. (2006) Sulfur, lead and helium isotopic compositions of sulfide minerals from the Dachang Sn-polymetallic ore district in South China: implication for ore genesis. Mineralogy \& Petrology, DOI 10.1007/s00710-006-0148-2. 